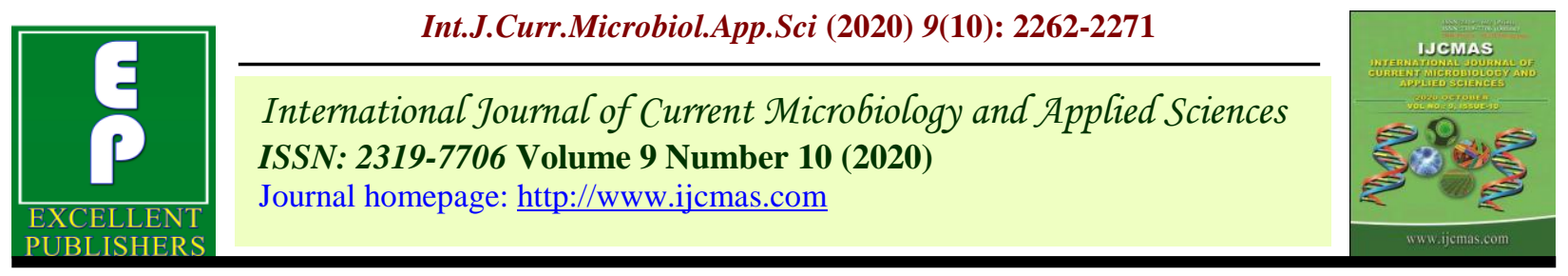

Review Article

https://doi.org/10.20546/ijcmas.2020.910.274

\title{
A Review on Different Horticultural Practices for Quality Improvement in the Fruit Crops
}

\author{
Sourav* and Ramesh Kumar Sadawarti \\ Department of Horticulture, School of Agriculture, \\ Lovely Professional University, (Punjab), India \\ *Corresponding author
}

K e y w o r d s
Pruning, Girdling,
Shoot bending,
Production

\section{A B S T R A C T}

In tropical and temperate fruit crops there are many practices to influence the floral initiation, fruit set, and quality of fruit crop carbohydrates nitrogen ratio appears one of the factor that control various practices such as pruning, girdling, shoot bending etc. To enhance off-season fruiting and flowering in different fruit crops. $\mathrm{C}: \mathrm{N}$ ratio of the fruit plants can be changed through simple horticultural practices like girdling and many more. Physiological parameters like leaf water potential and photosynthesis rate remained may increase under closer spacing as compared to the higher spacing under different levels of pruning. In this review we tried to study and discuss all those horticultural practices which enhance fruit quality, fruit production, which leads to high yield in fruit crops.

\section{Introduction}

Horticulture crops play vital role in enhancing agricultural produce. Carbon and nitrogen are the elements which play role in bearing of fruits. Although if tree's are in good health, disease free but if the $\mathrm{C}: \mathrm{N}$ ratio is not proper it will not bear the fruits, the growth and Fruiting of fruit crops are highly influenced by the proportion of carbohydrates and nitrogen. Girdling is one of the horticultural practice which helps in balancing $\mathrm{C}: \mathrm{N}$ ratio by stopping the flow of sap from xylem.
In fruit production yield and quality of fruit matter most for a grower for export purpose and for proper market value. Thinning helps in getting good size and proper shape of a fruit crop which as been studied by various workers, thinning is mostly done in guava to remove the flower which has low quality fruitset and this enhance the fruiting in quality season with maximum size and taste, earthing up is majorly practice in pineapple fruit crop which play vital role in anchorage of pineapple (Farid Hossain, 2016). Topping is an removal of shoot $15 \mathrm{~cm}$ or above which 
enhance the yield in grape vine Coombe 1959, pinching is also similar to topping but in pinching removal of shoot is done at $8 \mathrm{~cm}$ or below which also influence yield in grape wine . Notching technique also utilise in horticulture fruit production for enhancing yield as it enhance the lateral branches but it is more effective in bud break stage Vernier (1955). Bending of shoots is also an practice which enhance the fruit and flower production by reducing shoot growth, in this review we tried to collaborate all this Horticultural practices which helps in improving yield, quality, quantity, weight of fruits so that growers can get high and profitable price to their produce, this practices also has one beneficial effects that without using any chemical we can enhance yield and mange over fruit orchard. Kirti Bandhan and Kapil Mohan Sharma 2017 illustrated chart of artificial manipulation of $\mathrm{C}: \mathrm{N}$ ratio.

\section{Girdling or Ringing}

This is well known method to induce flower buds and fruiting in fruit crops, girdling or Ringing is one of the horticulture practice method which stops the downward flow of sap (food material) through phloem which enhance the flowering, fruit set and fruit size in horticulture plants. This method is ecofriendly were less or no chemicals are used for improving the production of horticultural plants, Gawankar et al., (2012) concluded in their Review concluded that girdling improves yield along with physical and chemical structure of a fruit without any chemical hazard, Rivas (2007) performed girdling experiment in citrus and concluded that reduction of fruit let abscission, increasing in chlorophyll content which directly increases in flowering and fruiting of citrus. Rivas et al., (2008) concluded that girdling increases the activities of leaf antioxidant enzymes and the soluble content of sugar. Girdling enhances foliar carbohydrates and plant hormones in the top parts of the girdled branches resulting in increases flowering (Khandaker et al., 2011). Mostafa and Saleh (2006) also performed experiment by using potassium spray along with girdling and concluded that spray increases the fruiting percentage per tree, Wright (2000) also performed experiment by using Fairchild Mandrin and Lisbon lemon and concluded that girdling increases the fruit number and ultimately the yield in mandarins and lemon. In such studies, girdling used as an effective method for improving the yield by proper source-sink utilization in perennial woody plants (Kumar et al., 2015).circular girdling of $2 \mathrm{~mm}$ on $50 \%$ main branches produced more flowering panicle, fruit size an yield, TSS, and TSS/acid ratio in Shahi litchi trees as compared to ungirdled branches of trees (Kumar et al., 2017). Jonhson and LaRue (2013) performed that remove the piece of bark from the base or trunk of the primary branches of nectarine and peach tree the cut was made $1 / 8$ or $3 / 16$ inch wide and observe that there was disruption in the carbohydrate flow in the phloem and other hand they are more available in the fruit growth and development. Roussos and Anastassios (2011) concluded that fructose, glucose and sucrose concentrations were increased in fruits from girdled primary branches of mandarin trees.

Ibrahim 2016 also performed girdling in 16 year old Washington navel orange and observed that girdling increases no. Of flowers, fruit set and yield in girdled tree then un-girdled tree. Haldankar (2014) performed girdling in jamun tree and concluded that girdling enhance the flowering and fruiting per branchlet, reduces flowering period then controlled plant. Khandakar (2011) performed girdling technique on wax jamun fruits and concluded that chlorophyll content, yield, fruit size as well as faster fruit growth increases in wax jamun due to girdling. More 
seed-pulp ratios in litchi have been found in the case of the girdling $x 40$ DAfS $x$ leaf elimination, which is in line with Singh et al., (2006), and Das et al., (2006). Rufato (2015) performed girdling on European pear variety "packham's Triumph" grafting on pyruscalleryana root stock and reported that due to girdling yield of pear increases. Ahmad 2009 performed girdling on olive (Oleaeuropaea L) and reported that fruitset, fruit size, weight of olive cultivar uslu has increased due to girdling.

Shinde (2014) observed high yield per tree in alphanso due to girdling in mango, hence girdling play vital role in enhancing fruit yield and flowering of various fruit crops which has been reported by various workers who worked on girdling. Ghadage et al., (2017) concluded that the girdling was recorded to increase the fruiting and flowering parameters of the mango cv Alphonso on July 15th with a width of $1.50 \mathrm{~cm}$.

\section{Bending of shoots}

Bending of shoots may define as reduction in shoot growth and to enhance flowering and fruiting of plant. Mamun et al., (2012) performed effect of fruit thinning and shoot bending on guava productivity by using BAU piyara-5,swarupkathi, Chiang Mai long and Chiang Mairound and concluded that bending shoot treatment give highest yield and 50\% fruit thinning shows more retention of fruit during off-season. (Mamun et al., 2012; Bagchi et al., 2008) found that significant variations have been observed as bending is used in guava to encourage off-season flowering. Bending cause more fruiting and flowering, as well as get more returns and regulate flowering by shoot bending (Mitra et $a l ., 2008)$. Bending frequently increased the polyphenol oxidase, tryptophan, lipid, catalase, proline and levels of peroxidase in bark, fruits and leaves, but decreased phenolics (Eassa et al., 2012).

Pierre-Fric Lauri and Jean - Marie lespinasse 2001 performed bending effect on genotype of apple by using two different varieties X3318 and changeover and concluded that bending effect varies with genotype in relation with growth and development of apple. Lauri et al., (1998) carried experiment by performing bending in cherry were INRA fercer grafted on dwarfing root shoottabel and other was control one and concluded that bending reduced the vigor of shoot which enhance flowering and fruiting in cherry (Table 1).

Table.1

\begin{tabular}{|l|l|l|}
\hline Plant response & Natural phenomena & Artificial manipulation \\
\hline Carbohydrates to N ratio & $\begin{array}{l}\text { Higher Carbon nitrogen ratio } \\
\text { enhances flowering }\end{array}$ & $\begin{array}{l}\text { Girdling, notching, pruning, } \\
\text { Nicking, time of fertilizer } \\
\text { application, cincturing. }\end{array}$ \\
\hline
\end{tabular}

\section{Pruning}

Pruning is an science and art of removing some plant part or cutting of infected plant parts for better and valuable growth. Adhikari et al., 2015 has shown that the $20 \mathrm{~cm}$ pruning plant at the beginning of May month may help minimise the rainy season and improve yield and output in the winter season crop. Susanto et al., (2019) performed Pruning by leaving four pairs of leaves tended to have more No of fruit and flower than by leaving eight pairs of leaves in "crystal" variety of guava (Gola et al., 2018). The fruit weight, 
fruits size, Highest, Sugar and the vitamin C contents was the obtained maximum trees prune at the (15th May) is most suitable pruning time to maximum fruits yield and quality in ber.

Pruning play vital role in guava fruit various workers worked on guava, Sawant (2018) observed that $50 \%, 30 \%$ and $25 \%$ pruning helps in growth characteristics of guava. Lian (2019) recently reported that $25 \%$ pruning helps in enhancing yield and fruit set in guava.

Leaf pruning is also one of the practice method as it improves the fruit volume and diameter of fruit. Feng (2015) reported that their is decreasing rate of grapes disease when it is leaf pruned were as pastore 2013 observed that leaf pruned grape shows enhancement in fruit production, yield of fruit crop.

Pruning application can significantly increase the fruit quality and yield of peach (Kumar et al., 2010), fruit yield of sweet cherries (Bennewitz et al., 2011), fruit yield of lemon (Ghosh et al., 2016).

Therefore, a combination of irrigation and root pruning may be a promising solution to regulating the size of the tree and reducing the detrimental effect of root pruning on the consistency of the fruit and the yield of the pear (Wang et al., 2014). Kumar and Rattanpal 2010 recorded that overall sugar levels were higher $(7.9 \%$ and $9.4 \%)$ in the elimination of half vegetative growth and lower $(7.1 \%$ and $7.4 \%)$ in the control trees, respectively, during both seasons. Mano et al., (2011) and Mano and Hamada (2005) have concluded that closer fig spacing favoured higher yields and higher growth. Also high fruit yield in the trees subjected to light pruning may be consequence of increased bearing area with decrease in pruning severity.
Abdel-Mohsen (2013) conclude that Pruning at long canes (10 buds per cane) recorded the highest fruitful buds percentage as well as the lost bud burst percentage while the opposite was true with respect short pruning (2 buds per cane, spur pruning) in crimson seedless grape variety.

Mohamed et al., (2011) concluded that pruning at a stage of one-third of the branches offered the maximum yield $(33.62 \mathrm{~kg}$ per tree) followed by a reduction of half of the branches (21.72 kg per tree) and tipping (31.47 kg per tree) compared to control trees (19.41 kg per tree) in plum.

Hassani and Rezaee (2007) conclude that severe pruning in peach that increases the fruit TSS. Mercier et al., (2008) conclude that pruning done by manually increases the TSS content in peach.

In apples low vegetative growth reduced fruit size. Therefore, pruning method i.e. by heading back can restore further vegetative growth and the development of new flower buds, resulting in increasing fruit size and fruit number (Han et al., 2011). In kinnow mandrin side pruning improved juice content, top pruning increased rag content and fruits from unpruned plants had thick peel. The increased juice weight in the fruits harvested from plants with pruning from both sides may be due to enhanced sunlight penetration and more nutrients availability to the plants (Nasir et al., 2016). Therefore, it is concluded that both side pruning in 'Kinnow' mandarin is more helpful to improve fruit yield and quality parameters under high density plantation

\section{Thinning}

Thinning is mainly done to reduce fruit load which is mainly practice in peach and nectarines (stone fruit), apple (pome fruit), grape vine, apricot, cherry, plum, kiwi fruit 
etc. Link (2000) carried experiment and concluded that as thinning increases , quality, storability, yield of fruit crops increases hence thinning is directly proportional to quality in fruits. Upreti (2019) observed that in papaya, seed wt. and fruit wt. were respectively increased by 39 and 52 per cent with the practicing of hand thinning and it also improves the shelf life of papaya fruit than practice with the chemical thinning.

Burge et al., (1987) performed thinning in kiwifruit vines and observed that fruit number is decrease were as fruit size increases which help for export purpose they also concluded that thinning didn't affect vegetative growth of kiwifruit. Thinning time also influences the number of cells and it has been found that the early 'Delicious' apple fruit thinned one week after full bloom has a marginally higher number of cells and a greater fruit size than the late thinning (Ouma, 2010). Clingeleffer and Petrie (2006) in grapes, reported that the fruit thinning practice gave highest fruit weight at the time of harvest.

Damerow and Blanke also performed thinning in apple and concluded that thinning play vital role in producing export quality fruit crop and also play vital role in depleting alternate bearing. Thus, thinning is to removal of some plants or plants parts, to make area for the growth of others but does not involve in cutting whole tree. Removal of plant part such as buds, branches and roots is known as pruning.

\section{Notching}

Singh in his experiment concluded and recommend that only 1 to 2 buds should be actively notched in one shoot for proper growth, Samuel et al., (1969) studied notching and pruning effect on fig (Ficus carica L) and observed effective result in growth of fig, various researchers worked notching on apple and fig to observe effective result, Duane W. Greene and Wesley R. Auto (1994) performed notching practice in apple (Malus domestica) and concluded that by notching 2-4 week before full blowing it enhance the shoot production and bud of an apple.

Notching technique play vital role in enhancing lateral branching (Suchter and Knapp 1929, Chandler 1925, Gardner 1939) Vernier 1955 noted that notching increases the growth of lateral shoot, but it is more effective when it is done at bud break stage.

\section{Bagging}

During maturity, many fruits should be bagged. By this bagging technique we can reduce the risks of physical damage and improves fruit colour at harvest time (Muchui et al., 2010). It is a major fruit conservation technique that not only protects the fruit from insect-pests and diseases, but also influences the quality of fruit by changing the microenvironment during fruit production (Son and Lee et al., 2008). Fruit bagging is one of the most significant methods for producing the quality of fruit and has long been used in production of fruits (Zhai et al., 2006). Mostly all fruit fly species are quarantine threats (Abbasi et al., 2009). Mainly which countries import the fruits bagging must be required (Qin et al., 2012) treatment combination of 50 percent fruit thinning and bagging with white polythene of guava may be considered depending on no. of fruits per plant, diameter of fruit, length of fruit, weight of fruit, thickness of mesocarp and yield per plant as well as guava fruit quality (Rahman et al., 2020).

\section{Earthing up}

Pineapple is only fruit crop were earthing up is mostly done Farid Hossain (2016) in his 
overview of world pineapple production reported that earthing up play vital role in better anchorage of pineapple and it should be done after fertilization and weeding in pineapple.

\section{Topping, pinching and cincturing}

$15 \mathrm{~cm}$ or more shoots removal is known as topping were as $8 \mathrm{~cm}$ or less shoots removal is known as pinching, Coombe 1959, Opera 1963 reported that by performing topping and pinching their is increasing in yield of grape vines, similarly Zeftaul and Weste (1970) performed topping, pinching and Cincturing in grape vine (Vitis vinifera) and observe growth and yield has been increased in grapevine. Cincturing, a circular ring is constructed around the main stem and similar to ringing/girdling method has been effective in preserving the carbon: nitrogen ratio and encouraging more fruit in litchi (Kumar et al., 2015) and Avocado (Nissim-Levi et al., 2008).

In conclusion, horticultural crops (fruit, vegetables, aromatical, etc.). Playing vital role in increasing agricultural production, among all fruit crops has high value in market so yield play vital role for growers to get some income and to improve their economy level. In this review we tried to study and discuss all those practices which helps in improving yield and growth of an fruit crops. Among all practices pruning is an most effective and can be done in each and every fruit crops for management and enhancement in yield of fruit crops, their is more research and work required in these practices so that grower should adopt it and enhance his or her production.

\section{References}

M. S. Gawankar, P. M. Haldankar, B. R. Salvi, Y. R. Parulekar, N. V. Dalvi, M.
M. Kulkarni, Y. S. Saitwal and N. A. Nalage. Effect of Girdling on Induction of Flowering and Quality of Fruits in Horticultural Crops-A Review January 2019

Ahmad M., Rahman H., Ahmad I. and Tariq M. S. 2009. Effect of girdling dates on fruit setting in Olive cv. Uslu. Pak. J. Agric. Res. 22: 3-4.

Mostafa E. A. M. and M. M. S. Saleh 2006. Response of balady Mandarin trees to girdling and potassium sprays under sandy soil conditions. Res. J. Agric. Biol. Sci. 2: 137-141.

Ramona C. and Florin S. 2015. Effect of tree girdling on some varieties of Chinese date (Ziziphus jujuba mill.). Scientific Papers. Series B Horticulture. Vol. LIX 37-42.

Rivas F., Erner Y., E. Alos, M. Juan, Almela V. and Agusti M. 2006.Girdling increases carbohydrate availability and fruit-set in citrus cultivars irrespective of parthenocarpic ability. J. Hortic. Sci. Biotech. 81: 289-295.

Rivas F., Gravina A. and Agustí M. 2007. Girdling effects on fruit set and quantum yield efficiency of PSII in two Citrus cultivars. Tree Physiol. 27: 527535.

Roussos P. A. and Tassis A. 2011. Effects of girdling, nitrogen, zinc and auxin foliar spray applications on mandarin fruit "Nova" quality characteristics. Emir. J. Food Agric. 23: 431-439.

Rufato L., De Rossi A., Giacobbo C. L. and Fachinello J. C. 2004.vegetative propagation of seven quince cultivars for utilization as pear rootstocks in Brazil. Acta Hortic. 658: 667-671.

Rufato L., Machado B. D., Luz A. R. and MarconFilho J. L. 2015.Effect of trunk girdling on growth and crop yield of 'packham's triumph' pear. Acta Hortic. 1094: 265-268.

Shao L. H., Deng L. and Qing L. Y. 1998. 
Effects of floral promotion or inhibition treatments on flowering of citrus trees and protein fraction in buds. J. Trop. Subtrop. Bot. 6: 124-130.

Shinde V. V., Dubale J. J., Haldankar P. M., Parulakar Y. R. and Thorat S. B. 2015. Effect of Ringing on Flowering and Yield of Mango Mangifera indica $\mathrm{L}$ var Alphonso. Asian Resonance. 3.

Singh V. K., Tiwari A. K. M., Singh D. K. and Pathak S. M. 2007.Effect of leaf number and area on the fruit growth of regular and biennial bearing mango (Mangifera indica L.) grown Under North Indian Conditions. Int. J. Fruit Sci. 6: 77- 91 .

Ticho R. L. 1970. Girdling, a means to increase avocado fruit production. California Avocado Society 1970-71 Yearbook. 54: 90-95.

Wright G. C. 2000. Girdling 'fairchild' mandarins and 'lisbon' lemons to improve fruit size Citrus and Deciduous Fruit and Nut Research Report, College of Agriculture and Life Sciences, the University of Arizona, Tucson, Arizona, 85721, pp. 15-18.

Ibrahim M. M., Mohamed A. O., Mohamed A. H. and Omar A. A. 2016. Effect of some girdling treatments on fruiting behaviour and physio-chemical properties of Washington navel orange trees. J. Agril. and Vet. Sci. 9: 58-65.

Khandaker M. M., Abm S. H., Normaniza O., and Amru N. B. 2011. Application of girdling for improved fruit retention, yield and fruit quality in Syzygium samarangense under field conditions. Int. J. Agric. Biol. 13: 18-24.

D.P.H. Tucker, T.A. Wheaton and R.P. Muraro2 Citrus Tree Pruning Principles and Practices1June 1994.

Lal Bahadur Chhetr, Bishnu Prasad Kandel Intensive Fruit Cultivation Technology of Citrus Fruits: High Density Planting: A Brief Review Journal of Agricultural
Studies, Vol. 7, No. 2.

Jonathan H. Cra Selected Cultural Techniques to Improve Production of Some Subtropical and Tropical Fruit Crops Acta Hort. 632, ISHS 2004 Publication supported by Can. Int. Dev. Agency (CIDA).

Menzel, C. M. and B. F. Paxton. The effect of cincturing at different stages of vegetative flush maturity on the flowering of litchi (Litchi chinensi Sonn.) Journal of Horticultural Science (1986) 61 (1) 135-13.

Hackney, C.R., M. Boshoff and M.J. Slabbert Everdon Estate, P O Box 479, Howick, 3290, RSA Increasing Yield of Young Hass Avocado Trees using the Cincturing Technique South African Avocado Growers' Association Yearbook 1995. 18:54-55.

Nandi, P., D. Roy, B. Ghosh and S. Kundu Effect of bending of shoots on flowering, yield and quality of guava cv. Khaja Journal of Applied and Natural Science 9 (3): 1365 - 1368 (2017).

Mamun, A., M. H. Rahman and M. A. Rahim Effect of Shoot Bending and Fruit Thinning on Productivity of GuavaJ. Environ. Sci. and Natural Resources, 5(2): 167 - 172, 2012

EL-Zeftawi, B. M. and WESTE, H. L. Effect of topping, pinching, cincturing, and PCPA on the yield of Zante currant (Vitis vinifera var.) Vitis 9, 184-188 (1970)

Hossain.MF1. World pineapple production: An overview. DOI: 10.18697/ajfand.76.15620.

Duane W. Greene and Wesley R. Autio Notching Techniques Increase Branching of Young Apple Trees J. Amer. Soc. Hort. Sci. 119(4): 678-682. 1994.

Damerow, L. A Novel Device for Precise and Selective Thinning in Fruit Crops to 
Improve Fruit Quality Acta Hort. 824, ISHS 2009.

Burge, G. K., C. B. Spence and R. R. Marshall (1987) Kiwifruit: Effects of thinning on fruit size, vegetative growth, and return bloom, New Zealand J. Exp. Agri., 15:3, 317-324, DOI: 10.1080/03015521.1987.10425577.

Tromp, J. Flower-bud formation and shoot growth in apple as affected by shoot orientation Acta Bot. Neerl. 17(3), June 1968

Tancrède Alméras, Joseph Gril, Evelyne Costes Bending of apricot tree branches under the weight of axillary growth: test of a mechanical model with experimental data Trees (2002) 16:515. DOI 10.1007/s00468-001-0139-1

Akiko Ito1, Hideaki Yaegaki, Hiroko Hayama, Shinnosuke Kusaba, Isomaro Yamaguchi and Hirohito Yoshioka. Bending Shoots Stimulates Flowering and Influences Hormone Levels in Lateral Buds of Japanese PearAkiko Ito1, Hideaki Yaegaki, Hiroko Hayama, Shinnosuke Ku. HORTSCIENCE 34(7):1224-1228. 1999.

Pierre-Éric Lauri1 Jean-Marie Lespinasse. 2001. Genotype of Apple Trees Affects Growth and Fruiting Responses to Shoot Bending at Various Times of Year. J. AMER. SOC. HORT. SCI. 126(2): 169-174.

Lauri, P.E.. The effects of bending on the growth and fruit production of INRA FERCER ${ }^{\circledR}$ SWEET CHERRYActa Hon. 468, ISHS 1998.

Nissim-Levi A, Farkash L, Hamburger D, Ovadia R, Forrer I, Kagan S and OrenShamir M (2008). Light-scattering shade net increases branching and flowering in ornamental pot plants. $\mathrm{J}$ of Hort Sci Biotech 83(1): 9-14.

Kumar A, Pandey SD, Patel RK, Singh SK, Srivastava K and Nath V (2015). Induction of flowering by use of chemicals and cincturing in 'Shahi' litchi. Ecoscan, 7 (Special Issue): 493496.

Kumar, A., Pandey, S. D., Patel, R. K., Srivastava, K., Tripathi, M., and Nath, V. (2017). Effect of girdling on flowering and fruiting of litchi (Litchi chinensis) in subtropics of Bihar. Indian Journal of Agricultural Sciences, 87(3), 397-401.

Khandaker M. M., Abm S. H., Normaniza O., and Amru N. B. 2011. Application of girdling for improved fruit retention, yield and fruit quality in Syzygium samarangense under field conditions. Int. J. Agric. Biol. 13: 18-24.

Johnson R. S. and LaRue J. 2003. Girdling Tree. pp. 60-61.

Adhikari, S., and Kandel, T. P. (2015). Effect of time and level of pruning on vegetative growth, flowering, yield, and quality of guava. International journal of fruit science, 15(3), 290-301.

Kumar, M., Rawat, V., Rawat, J. M. S., and Tomar, Y. K. (2010). Effect of pruning intensity on peach yield and fruit quality. Scientia Horticulturae, 125(3), 218-221.

http://doi.org/10.1016/j.scienta.2010.03. 027

Bennewitz, E. von, Fredes, C., Losak, T., Martinez, C., and Hlusek, J. (2011). Effects on fruit production and quality of different dormant pruning intensities in 'Bing'/'Gisela ${ }^{\circledR 6} 6$ ' sweet cherries (Prunus avium) in Central Chile. Ciencia e Investigacion AGRARIA, 38(3), 339-344. http://doi.org/10.4067/S071816202011000300003

Ghosh, A., Dey, K., Bhowmick, N., Medda, P. S., and Ghosh, S. K. (2016). Impact of different pruning severity and nutrient management on growth and yield of lemon cv. Assam lemon (Citrus limon Burm.). Vegetos, 29(1), 25-32. 
http://doi.org/10.5958/2229-

4473.2016.00007.0

Susanto, S., Melati, M., and Aziz, S. A. (2019). Pruning to Improve Flowering and Fruiting of 'Crystal' Guava. AGRIVITA, Journal of Agricultural Science, 41(1), 48-54.

Wang, Y., Travers, S., Bertelsen, M. G., Thorup-Kristensen, K., Petersen, K. K., and Liu, F. (2014). Effect of root pruning and irrigation regimes on pear tree: growth, yield and yield components. Horticultural

Science, 41(1), 34-43.

Abdel-Mohsen, M. A. (2013). Application of various pruning treatments for improving productivity and fruit quality of crimson seedless grapevine. World Journal of Agricultural Sciences, 9(5), 377-382.

Mohamed SM, Fayed TA, El-Shrief HM, Mokhtar OS (2011). Effect of heading cut levels, bending and NAA on spurs formation, yield and fruit quality of sun gold plum cultivar. J. Hort. Sci. Ornamental Plants 3(3): 232-243.

Han L, Soulij C, Boudon F, Dasilva D, Cokelamer T, Pradal C, Rouan L, Costes E (2011) Sensitivity analysis of light interception to geometrical traits of apple trees: an in silico study based on MAppleT model. 9th International 635 International Journal of AgriScience Vol. 3(8): 628-635, August 2013 Symposium on Modeling in Fruit Research and Orchard Management.

P.A. Roussos and T. Anastassios, Effects of girdling, nitrogen, zinc and auxin foliar spray applications on mandarin fruit "Nova" quality characteristics. J Food Agric, 23(5), 2011, 431-439.

Ghadage, N., Patil, S., Khopade, R., Shah, N., and Hiray, S. (2017). Effect of time and width of girdling on flowering and yield of mango (Mangifera indica L.) cv. Alphonso. International Journal of
Chemical Studies, 5(6), 1580-1583.

Singh, V.K., Tiwari, A.K.M., Singh, D.K. and Pathak, S.M. 2006. Effect of leaf number and area on the fruit growth of regular and biennial bearing mango (Mangifera indica L.) grown under north Indian conditions. Int. J. Fruit Sci, 6: 77-91.

Upreti, R. (2019). Effect of Fruit Thinning and Defoliation on Yield and Quality of Papaya (Carica papaya) cv. Red Lady in Chitwan. Acta Scientific Agriculture, 3, 130-136.

Mitra, S. K., Gurung, M. R. and Pathak, P. K. (2008). Sustainable guava production in West Bengal, India. Acta Hort. 773, 179-182.

Rivas, F., F. Fernando and M. Agustí, 2008. Girdling induces oxidative damage and triggers enzymatic and non-enzymatic antioxidative defences in Citrus leaves. Environ. Exp. Bot., 64: 256-263

Kumar Y, Rattanpal HS. Effect of pruning in guava planted at different spacings under Punjab conditions. Indian J. Hort. 2010; 67: 115-119.

Gola, A. Q., Jakhro, M. I., khan Tareen, A., Mastoi, M. S., and Khosa, M. A. (2018). 10. Influence of pruning on fruits production of jujube Ziziphus mauritiana Lam. Pure and Applied Biology (PAB), 7(4), 1261-1267.

Mano, T. and K. Hamada, 2005. Effects of close planting on growth, fruit quality and yield in young fig tree. KinkiChugoku-Shikoku Agric. Res., 6: 72-75.

Mano, T., Y. Mizuta and T. Moriguchi, 2011. Super-high density planting of fig (Ficus carica L.) for early recovery from sick soil and low temperature injury. Hort. Res., 10: 367-373.

Umara, M., Ahmada, S., Haider, S. T. A., and Nazb, S. (2017). Effect of Pruning to Improve Yield and Fruit Quality of 'Kinnow' Mandarin Plants under High Density Plantation. 
Nasir, M., Khan, A.S., Basra, S.A., and Malik, A.U. 2016. Foliar application of moringa leaf extract, potassium and zinc influence yield and fruit quality of 'Kinnow' mandarin. Scientia Horticulturae, 210: 227-235.

Ouma, G. (2010) Flowering, Pollination and fruit set in fruit trees. Lambart Academic Publisher Berlin, Germany 138pp.

Das, B., Jana, B. R., Dey, P. And Nath, Vishal. 2006. Assimilate partitioning behaviour in relation to fruit growth in 'Shahi'litchi. Int. J. Fruit Sci., 11: 8898.

Muchui, M.N., F.M. Mathooko, C.K. Njoroge, E.M. Kahangi, C.A. Onyango and E.M. Kimani, 2010. Effect of perforated blue polyethylene bunch covers on selected postharvest quality parameters of tissue cultured bananas (Musa Spp.) cv. Williams in Central Kenya. J. Stored Prod. Postharvest Res., 1: 29-41.

Son, I.C. and C.H. Lee, 2008. The effects of bags with different light transmittance on the berry cracking of grape "Kyoho". Hortic. Environ. Biotechnol., 49: 98-103.

Abbasi, N.A., M. Yaseen, T. Ahmad and I.H. Kakar, 2009. Implementation of Good Agricultural Practices (GAP) in
Horticulture Sector in Pakistan. 29 June-3 July 2009, Yogyakarta, Indonesia.

Zhai, H., C. Ren, E.M. Li, D.C. Shi, G.Y. Lin and X.Y. Liu, 2006. The effect of different bagging periods on the quality of red Fuji apple in Weibei dry land. J. Northwest For. Univ., 20: 188-120.

Qin, S.J., F.D. Li, D.G. Lv and W.S. Gao, 2012. Effect of preharvest bagging on fruit epidermis epiphyte community structure of "Red Fujic apple. MiddleEast J. Sci. Res., 11: 1475-1480.

Rahman, H., Akter, A., Rahman, J., Riad, M. I., and Rahman, M. M. (2017). Effect of fruit thinning and bagging on the yield and quality of guava. Research and Reviews: J Agric Sci Tech, 6, 20-27. Rahman, H., Akter, A., Rahman, J., Riad, M. I., and Rahman, M. M. (2017). Effect of fruit thinning and bagging on the yield and quality of guava. Research and Reviews: J Agric Sci Tech, 6, 2027.

Clingeleffer PR and Petrie PR. "Crop thinning (hand versus mechanical), grape maturity and anthocyanin concentration: outcomes from irrigated Cabernet Sauvignon ("Vitis vinifera L.") in a warm climate". Australian Journal of Grape and Wine Research 12.1 (2006): 21-29.

\section{How to cite this article:}

Sourav and Ramesh Kumar Sadawarti. 2020. A Review on Different Horticultural Practices for Quality Improvement in the Fruit Crops. Int.J.Curr.Microbiol.App.Sci. 9(10): 2262-2271. doi: https://doi.org/10.20546/ijcmas.2020.910.274 